\title{
Detecção Sorológica do Vírus A da Videira em Vinhedos do Estado de São Paulo*
}

\author{
Hugo Kuniyuki ${ }^{1 * *}$, Jorge A. M. Rezende ${ }^{2 * *}$, Valdir A. Yuki ${ }^{1} \&$ Juarez A. Betti $^{1}$ \\ ${ }^{1}$ Centro de Pesquisa e Desenvolvimento de Fitossanidade, Instituto Agronômico, Cx. Postal 28, CEP 13001-970, \\ Campinas, SP, e-mail: hkuniyuk @iac.sp.gov.br; ${ }^{2}$ Departamento de Entomologia, Fitopatologia e Zoologia Agrícola, \\ ESALQ/USP, Cx. Postal 9, CEP 13418-900, Piracicaba, SP
}

(Aceito para publicação em 11/06/2002)

Autor para correspondência: Hugo Kuniyuki

\begin{abstract}
Serological detection of the Grapevine virus $A$ in vineyards of the State of São Paulo, Brazil

This paper reports the serological detection of Grapevine

virus A (GVA) in the vineyards of the State of São Paulo, Brazil. The GVA was detected mainly in grapes (Vitis spp.) infected by Kober stem grooving.
\end{abstract}

A doença da videira (Vitis spp.) conhecida por acanaladura do lenho de Kober ("Kober stem grooving", KSG) pertencente ao complexo do "grapevine rugose wood" (GRW), vem sendo atribuída a um vírus de aproximadamente $800 \mathrm{~nm}$ de comprimento, denominado vírus A da videira (Grapevine virus A, GVA), gênero Vitivirus (Chevalier et al., J. Phytopathol. 143:369-373. 1995; Choueiri et al., Proceedings. 12th. Meeting ICVG. 1997.pp.39-40.), identificado com base nos sintomas de acanaladuras ou sulcos longos no lenho de plantas da videira indicadora Kober 5BB (Figura 1).

No Estado de São Paulo, a ocorrência do KSG já é conhecida, afetando algumas importantes variedades de copa e de porta-enxerto de videira (Kuniyuki \& Costa, Summa Phytopathologica 18:13. 1992).

Com o objetivo de determinar a ocorrência do GVA nos vinhedos de São Paulo e de verificar o possível relacionamento desse vírus com o KSG, foi aplicado o teste de DAS-ELISA, usando um kit comercial (Agritest, Valenzano, Italia), segundo o procedimento desenvolvido por Boscia et al. (Arch. Virol. 127:185194. 1992). As fontes de antígeno foram tecidos de floema de ramos em início de dormência de plantas infetadas. As amostras foram consideradas positivas quando os valores das absorbâncias $\left(\mathrm{A}_{405}\right)$ foram três vezes maiores aos do controle negativo do kit e das plantas sadias.

As reações no teste imuno-enzimático, com duas repetições, foram positivas para 12 de 16 plantas afetadas pelo KSG, das variedades Itália, Niagara Rosada e Kober 5BB. Três de nove plantas envolvendo cinco variedades afetadas pela doença "Rupestris stem pitting" (RSP) deram também reações positivas (Itália, Benitaka e Rupestris du Lot). Cinco plantas consideradas

\footnotetext{
*Apoio PRONEX.

** Bolsistas do CNPq
}

sadias, mediante testes biológicos, apresentaram reações semelhantes à do controle negativo do kit.

Os resultados demonstraram a ocorrência do GVA nos vinhedos paulistas, principalmente em plantas afetadas pela doença KSG. Os casos negativos em amostras com KSG, provavelmente decorreram do fato do GVA apresentar baixa concentração e distribuição irregular nos tecidos da planta hospedeira, além do seu reduzido poder imunogênico (Boscia et al., Arch. Virol. 127:185194. 1992). Os casos positivos em videiras com RSP, recentemente atribuída ao Rupestris stem pitting associated virus (RSPaV), gênero Foveavirus (Meng et al., J.Gen. Virol. 79:2059-2069. 1998; Zhang et al., Phytopathology 88:1231-1237. 1998), indicam possível ocorrência de infecção simultânea com o GVA. Essa hipótese é aceitável, uma vez que os sintomas de acanaladuras no lenho demoram três a quatro anos para se tornarem evidentes em plantas de crescimento vigoroso, o que muitas vezes não acontece com o porta-enxerto Kober 5BB sob condições de canteiro.

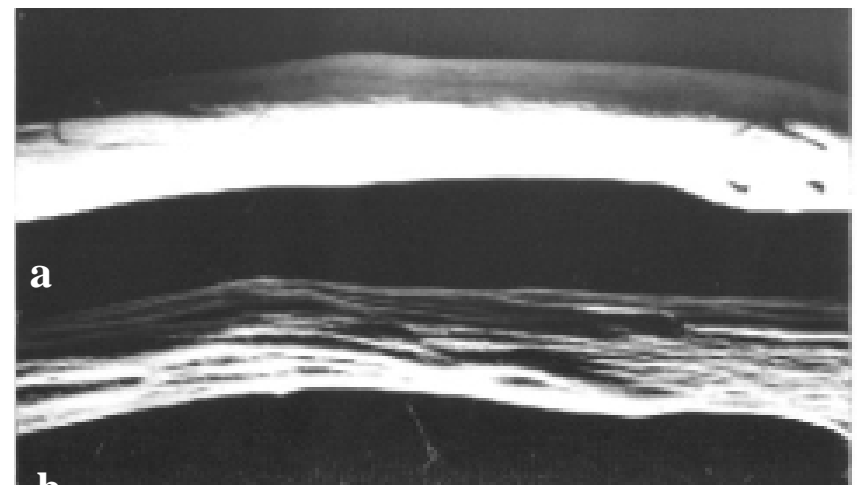

FIG. 1 - Acanaladura do lenho no porta- enxerto de videira (Vitis spp.) Kober 5BB. Planta afetada (b), ao lado de uma sadia (a). 